\title{
Anesthesia Management of Oculocardiac Reflex in Strabismus Surgery: A Case Study
}

\author{
Diva Zuniar Ritonga, ${ }^{1}$ Dedi Fitri Yadi, ${ }^{1,2}$ Muhamad Adli $^{3}$ \\ ${ }^{1}$ Departement of Anesthesiology and Intensive Care, Faculty of Medicine Universitas Padjadjaran/ \\ Dr. Hasan Sadikin General Hospital Bandung, Indonesia, ${ }^{2}$ Trainee Ophthalmic Anesthesia National \\ Eye Center Cicendo Eye Hospital, ${ }^{3}$ Anesthesia Staff National Eye Center Cicendo Eye Hospital
}

\begin{abstract}
There are various types of eye surgery with each requires special attention in anesthesia management. Strabismus surgery has several risks that need to be considered; one of which is oculocardiac reflex. The oculocardiac reflex is a condition characterized by decreased heart rate caused by the pressure on the globe or by traction on the extraocular muscles and conjunctiva or the orbital structures. This reflex can manifest as an asystole if left untreated. This is a case report of a 19-year-old male with ASA classification 1 presented with esotropia of left and right eyes. General anesthesia was used for anesthesia with $100 \mathrm{mcg}$ fentanyl, $100 \mathrm{mg}$ propofol, and $25 \mathrm{mg}$ atracurium for induction and, for airway management, LMA size 3 was used. Sevoflurane 2-3 vol\% with oxygen and nitrous oxide was given as maintenance. During the surgery, the heart rate dropped to 35 beats per minute when the operator pulled the medial rectus muscle in the first eye. The surgery was then paused and the heart rate was incrementally increased to 65 beats per minute without any other intervention. Then, as the operator pulled the medial rectus muscle in the second eye, the heart rate decreased to 55 beats per minute and the surgery continued with the heart rate slowly increased without any intervention. The remaining surgery time was uneventful. Knowledge and early intervention of oculocardiac reflex conditions should be well understood by all anesthesiologist to avoid more catastrophic conditions.
\end{abstract}

Keywords: Anesthesia, oculocardiac reflex, strabismus

\section{Manajemen Anestesi untuk Reflek Okulokardiak pada Operasi Strabismus: Laporan Kasus}

\begin{abstract}
Abstrak
Terdapat banyak jenis operasi pada mata, setiap operasi membutuhkan penanganan anestesi yang khusus. Operasi strabismus memiliki beberapa risiko yang perlu menjadi perhatian, salah satunya adalah refleks okulokardiak. Refleks okulokardiak merupakan konisi yang ditandai dengan penurunan denyut jantung disebabkan oleh tekanan pada bola mata atau penarikan pada otot-otot ekstraokular pada konjungtiva atau strukur orbita. Tanpa penanganan refleks ini dapat menyebabkan asistol. Sebuah laporan kasus mengenai laki-laki 19 tahun dengan klasifikasi ASA 1, dengan esotropi pada kedua mata yang akan dilaksanakan operasi strabismus. Anestesi umum dilaksanakan dengan obat-obat induksi fentanil $100 \mathrm{mcg}$, propofol $100 \mathrm{mg}$, dan atrakurium $25 \mathrm{mg}$, LMA ukuran 3 digunakan untuk managemen jalan napas. Sevofluran 2-3\% dengan oxygen dan nitrous oxide digunakan untuk rumatan. Sewaktu operasi denyut nadi menurun sampai 35 kali per menit ketika operator menarik otot medial rektus pada mata pertama, kemudian operasi diminta dihentikan sementara, kemudian denyut nadi meningkat perlahan kembali ke 65 kali per menit tanpa pemberian intervensi lain. Kemudian, ketika operatot menarik otot medial rektus pada mata kedua denyut jantung menurun ke 55 kali per menit, operasi dilanjutkan dan denyut jantung meningkat tanpa intervensi lain. Operasi berlangsung tanpa kejadian lain. Pengetahuan dan penanganan awal kondisi refleks okulokardiak perlu diketahui oleh dokter anestesi untuk mencegah kondisi yang lebih berbahaya.
\end{abstract}

Kata kunci: anestesi, refleks okulokardiak, strabismus

Correspondence: Dedi Fitri Yadi, dr. SpAn-KAR. M. Kes, Departement of Anesthesiology and Intensive Care, Faculty of Medicine Universitas Padjadjaran/Dr. Hasan Sadikin General Hospital Bandung, Indonesia, Jl. Pasteur No. 38 Bandung 40161,Phone 022-2038285, Email dedifyadi@yahoo.com 


\section{Introduction}

Strabismus is a malalignment of the visual axes which may be accompanied by diplopia, amblyopia, and loss of stereopsis. It affects approximately $3 \%$ of the population. Strabismus surgery is the most common pediatric ocular operation performed in the United States and it entails various techniques to weaken (recession) or to strengthen (resection) an extraocular muscle. ${ }^{1}$

Traction on extraocular muscles, pressure on the eyeball, administration of a retrobulbar block, and trauma to the eye can elicit a wide variety of cardiac dysrhythmias, ranging from bradycardia and ventricular ectopy to sinus arrest or ventricular fibrillation, which are referred to as the oculocardiac reflex. This reflex is most commonly encountered in pediatric patients undergoing strabismus surgery although it may be seen in all age groups and during a variety of ocular procedures, including cataract extraction, enucleation, and retinal detachment repair. ${ }^{2}$

Various maneuvers to abolish or obtund the oculocardiac reflex have been promulgated. None of these methods have been consistently effective, safe, and reliable. Moreover, some anesthesiologists claim that prior intravenous administration of atropine may yield more serious and refractory cardiac dysrhythmias than the reflex itself. Thus, this reflex is a serious situation that needs special attention from both the surgeon and the anesthesiologist. ${ }^{1,2}$

\section{Case Description}

A healthy 19-year-old male presented with congenital esotropia of the left and right eyes was consulted for elective bimedial rectus muscle recession of both eyes. Patient complained of having squint eyes, both of his eyes were crossed inward since birth. Patient denied double vision, and admitted to have recurrent headaches and previously had a positive Mantoux test and was received antituberculotic drugs for two weeks, with a negative sputum smear after the two weeks and antituberculotic drugs were stopped. There was no history of allergies and other comorbidities. The patient has no history of other congenital diseases. There was no history of previous surgery and anesthesia. On physical examination, the patient was fully alert with a blood pressure of 121/86 $\mathrm{mmHg}$, pulse rate of 82 beats per minute, breath rate of 20 breath per minute, and oxygen saturation of $99 \%$. The pupil was round and same in size, light reflexes were normal in both eyes, eyeball position was esotropia. Other physical examinations and laboratory findings were within normal limits.

Patient was diagnosed withleftand righteye congenital esotropia and scheduled for squint surgery under general anesthesia. Patient was fasted 6 hours before surgery and NIBP, $\mathrm{SpO}_{2}$, ECG, and $\mathrm{EtCO}_{2}$ were used to monitor the patient intraoperatively. General anesthesia induction was done using $100 \mathrm{mcg}$ fentanyl, $100 \mathrm{mg}$ propofol, and $25 \mathrm{mg}$ atracurium

Table I Recommended Technique for Intraocular Surgery

\begin{tabular}{llll}
\hline Induction & $\begin{array}{l}\text { IV induction with opioid and } \\
\text { propofol 3-5 mg/kgBW }\end{array}$ & or & $\begin{array}{l}\text { Gas induction with sevoflurane } \\
\text { followed by IV access }\end{array}$ \\
RAirway & $\begin{array}{l}\text { RAE endotracheal tube following } \\
\text { paralysis with nondepolarizing } \\
\text { muscle relaxant }\end{array}$ & & $\begin{array}{l}\text { FLexible LMA inserted with or } \\
\text { without paralysis }\end{array}$ \\
Maintenance & $\begin{array}{l}\text { TIVA: Propofol TCI (or 6-10 mcg/ or } \\
\mathrm{kg} / \text { hour) + remifentanil 0,2-0,5 } \\
\mathrm{mcg} / \mathrm{kgBW} / \text { minute }\end{array}$ & $\begin{array}{l}\text { Inhaled sevoflurane/desflurane } \\
+ \text { regular administration of }\end{array}$ \\
& & $\begin{array}{l}\text { NDMR in conjunction with } \\
\text { neuromuscular monitoring. } \\
\text { IPPV throughout }\end{array}$ \\
\hline
\end{tabular}

Sumber: Davies dkk. ${ }^{3}$ 


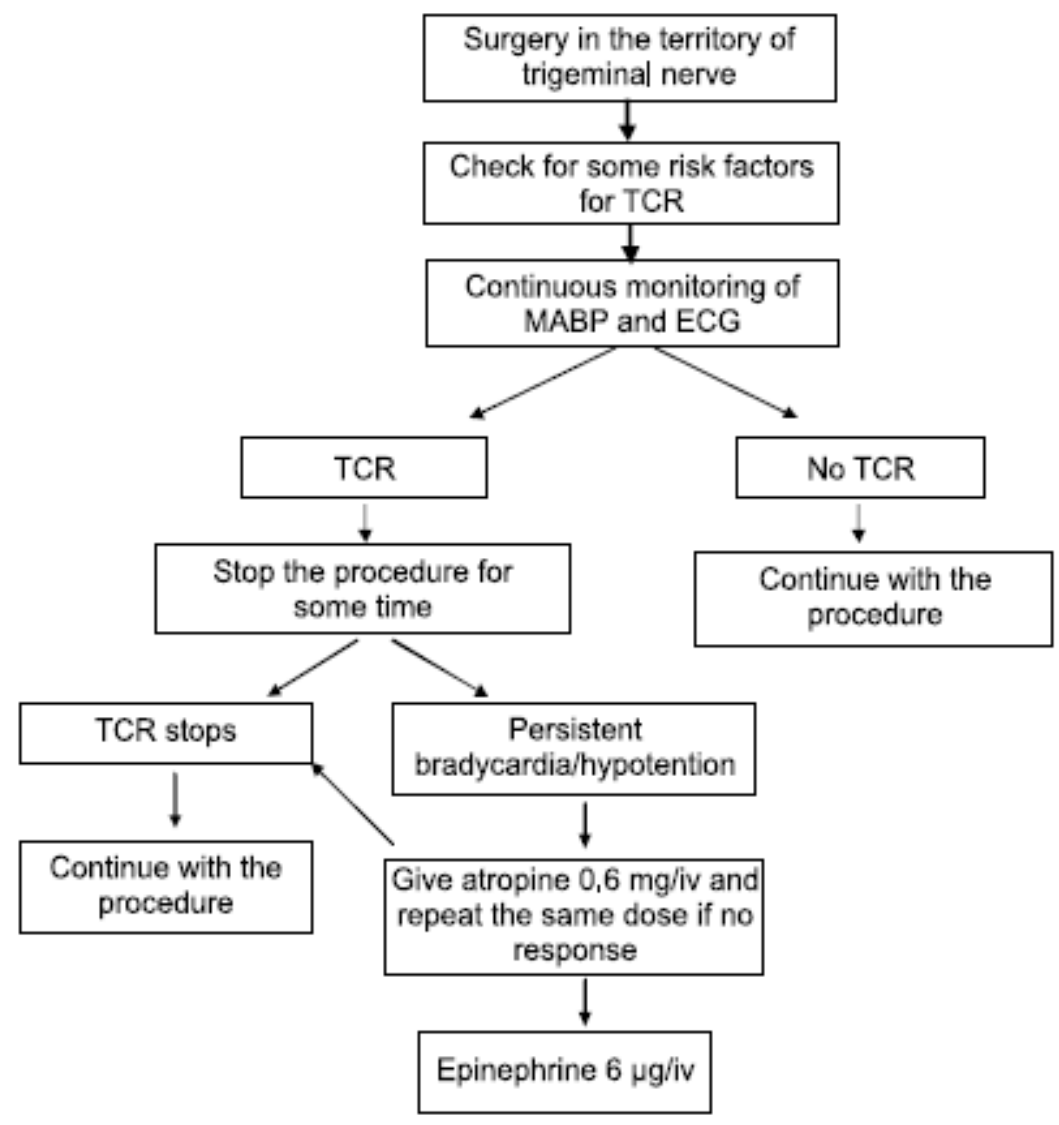

Figure 1 Management of Trigeminocardiac Reflex Sumber: Arasho dkk. ${ }^{11}$

while LMA was used for airway management. Sevoflurane 2-3 volume percent with oxygen and nitrous oxide $\mathrm{FiO}_{2} \quad 50 \%$ was given as maintenance. Intravenous ondansetron 4 $\mathrm{mg}$ and dexamethasone $5 \mathrm{mg}$ were given. Surgery lasted for two hours with minimum bleeding. Intraoperative hemodynamics intraoperative was relatively stable except for two occurrences of bradycardia, in which the heart rate dropped from 65 to 35 beat per minute when the operator pulled the medial rectus muscle on the right eye, causing the anesthesiologist to ask the surgeon to stop surgery. The heart rate then increased to 65 beats per minute without any intervention. Surgery was continued on the right eye without any unremarkable event. As the operator pulled the medial rectus muscle in the left eye, the heart rate decreased from 68 to 55 beats per minute but the surgery continued and the heart rate gradually increased without any intervention.
After the surgery, the patient was transferred to the recovery room in stable condition. Patient received oxygen supplementation using a nasal cannula of 3 liters per minute and was positioned in head up $30^{\circ}$. Patient complained of nausea and was, therefore, given intravenous ondansetron. Then, the patient was moved to the ward and was given tramadol $100 \mathrm{mg}$ and ketorolac 30 $\mathrm{mg}$ in $500 \mathrm{~mL}$ of ringer lactate for 8 hours as analgesics. Patients were allowed to go home 1 day postoperatively.

\section{Discussion}

Strabismus is usually idiopathic, although secondary strabismus can occur in cases of trauma, infection, space-occupying lesions, immunological, endocrine, or inflammatory conditions that cause muscle paralysis. ${ }^{1,3}$ Strabismus surgery is performed to correct functional and cosmetic deficits, and it entails 


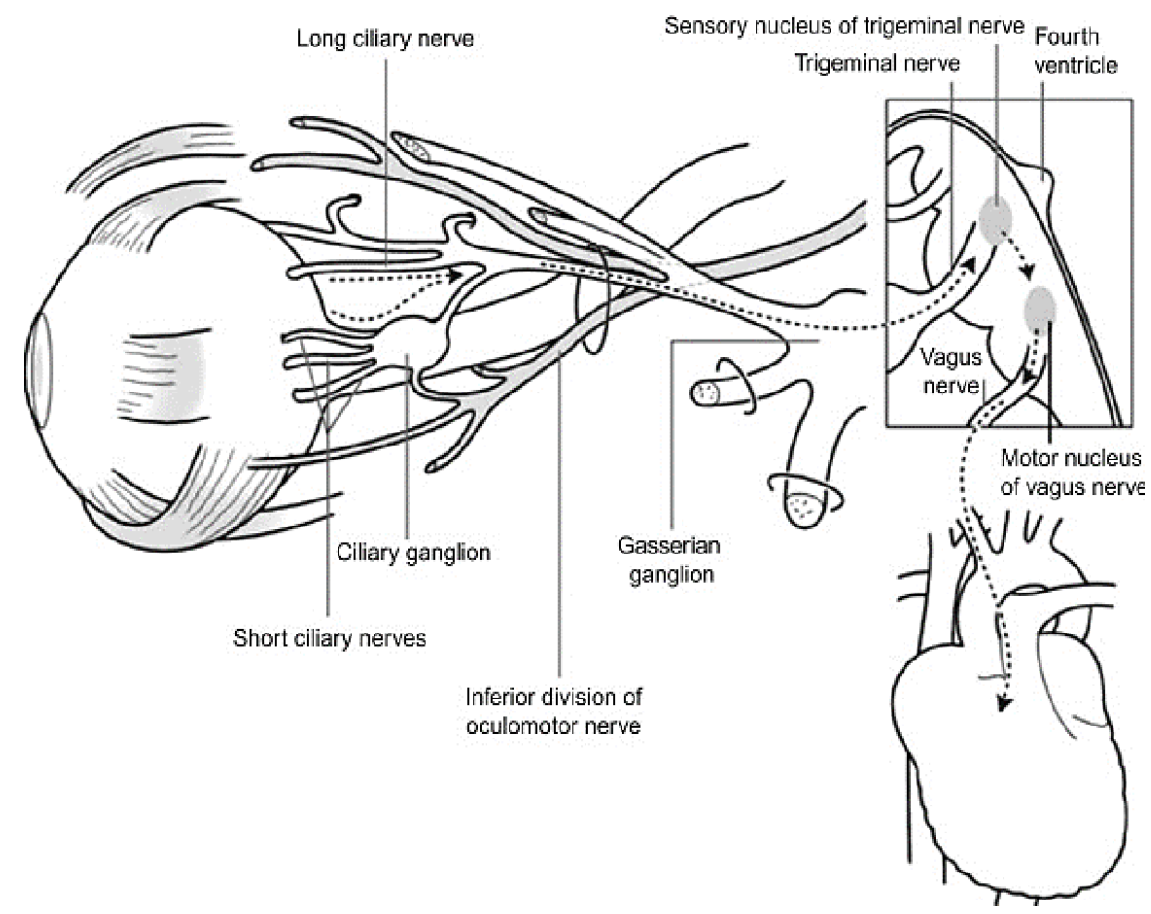

Figure 2 Occulocardiac Reflex Pathway Sumber: Jean dkk. ${ }^{6}$

various techniques to weaken an extraocular muscle by moving its insertion on the globe (recession) or to strengthen an extraocular muscle by eliminating a short strip of the tendon or muscle (resection). ${ }^{1}$ This procedure is usually performed as a one-day surgery but the high incidence of PONV sometimes indicates hospitalization. The oculocardiac reflex is caused by manipulation of the extraocular muscles, and strabismus surgery is one of the most well known procedures causing oculocardiac reflex. ${ }^{1,2,8}$

Preoperative fasting is required in patients to reduce the risk of aspiration of food or fluid while under anesthesia. Although rare, this might lead to a very serious complication. Fasting time guideline is appled to healthy patients who are about to undergo elective surgery. Patients with a history of diabetes or GERD may need a longer fasting time. ${ }^{2-4}$

Airway management must be adjusted according to the procedure to be performed. LMA can be used in older pediatric patients for most eye procedures. LMA has the advantage of reducing the cough rate at the end of the operation and controlled ventilation with the use of muscle relaxants is possible. Therefore, many anesthetists used the LMA in eye surgery for suitable patients. If the patient is intubated, deep extubation is best chosen but is contraindicated in emergency surgery or in patients with difficult airway management, on which lidocaine administration can be given in an extubation on conscious state to reduce the effect of extubation on $\mathrm{IOP}^{5}$ In this case, the patient was fasted for 6 hours before surgery and the induction went smooth. The LMA was used for airway management with no problems until the end of the procedure.

Isoflurane or sevoflurane may be the preferred volatile anesthetic for maintenance. Total intravenous anesthesia (TIVA) using propofol has the advantage of reducing the risk of postoperative nausea and vomiting (PONV) because propofol has antiemetic properties. The use of nitrous oxide in eye surgery is limited due to increased risk of PONV and it will diffuse from the blood into the gas-filled space in the body. This should be avoided in vitreoretinal surgery in which 
intraocular gas bubbles of sulfur hexachloride or perfluoropropane are inserted into the eye to compress the dislodged surface. . $3,3,6^{2}$

Oculocardiac reflex is triggered by pressure on the globe and by traction on the extraocular muscles as well as on the conjunctiva or the orbital structures. this reflex is a part of the trigeminocardiac reflex, which is defined as the sudden onset of parasympathetic dysrhythmia, sympathetic hypotension, apnea, or gastric hypermotility during stimulation of any of the sensory branches of the trigeminal nerve. The reaction subsides with cessation of the stimulus. However, some patients may develop severe bradycardia, asystole, and arterial hypotension which require intervention. The risk factors already known to increase the incidence of trigeminocardiac reflex include hypercapnia, hypoxemia, light general anesthesia, age (which is more pronounced in children), the nature of the provoking stimulus strength and duration, and also potent narcotic agents (sufentanil and alfentanil), beta-blockers and calcium channel blockers. ${ }^{1,11}$

The oculocardiac reflex is quite common during eye surgery in pediatric patients and even occurs in up to $60 \%$ of children who undergo strabismus surgery. This reflex has afferent innervation of the ophthalmic division of the trigeminal nerve, relayed through the sensory nucleus in the 4th ventricle, with efferent impulses via the vagus nerve. Surgical traction of the extraocular muscles or pressure on the eyeball can cause bradycardia, and sometimes a junctional rhythm, atrioventricular block, ectopic atrium, or ectopic ventricle. The oculocardiac reflex can also be attenuated by application of a topical local anesthetic agent to the eye, such as tetracaine eye drops, or blocking afferent passage with a peribulbar block although this block are not usually used in children because of the risk of perforation. Sevoflurane has a lower tendency to provoke this reflex than halothane. The incidence of significant bradycardia is doubled at high carbon dioxide levels, on which controlled ventilation should be considered. The oculocardiac reflex is more likely to occur with rocuronium administration than with atracurium. Children who exhibit oculocardiac reflexes are more likely to develop PONV and should receive antiemetics during anesthesia. ${ }^{2-5}$

A variety of maneuvers to abolish or blunt the oculocardiac reflex have been tried. None of these methods have been consistently effective, safe, and reliable. The use of atropine as a prevention agent is questioned because cholinergic blockade reduces but does not totally prevent either bradycardia or hypotension in animals. In addition, atropine may cause serious cardiac arrhythmias itself, especially when halothane is the primary anesthetic agent and hence the dose must be carefully chosen. ${ }^{1,11}$

If a cardiac dysrhythmia appears, initially the surgeon should be asked to cease operative manipulation then anesthetic depth and ventilatory status should be evaluated. Commonly, heart rate and rhythm return to baseline within 20 seconds after these measures. The reflex is attenuated with repeated manipulation. Bradycardia is less likely to recur, probably secondary to fatigue of the reflex arc at the level of the cardioinhibitory center. ${ }^{1,11}$

The patient in this case had two occurrences of oculocardiac reflexes. In the first incident, the patient heart rate dropped to $35 \mathrm{bpm}$. The operation was ceased and the heart rate slowly rose in less than 20 seconds without any additional intervention. The second oculocardiac reflex appeared in the second eye but the heart rate did not drop as much as the first, just to about $55 \mathrm{bpm}$, so the surgery was not interrupted and the heart rate slowly rose. This showed one of the criteria of oculocardiac reflex which was thought to be due to the fatigue of the reflex arc.

Strabismus procedure has a high incidence of PONV. The oculocardiac reflex also increases the incidence of PONV. Because of this condition, anesthesiologists should pay attention to multimodal PONV prophylaxis using serotonin antagonists such as ondansetron $100 \mathrm{mcg} / \mathrm{kg}$ or dexamethasone. If PONV rescue using repeated doses of 
serotonin antagonists provides only minimal effectiveness, it is necessary to consider different classes of antiemetics. ${ }^{7,10}$

Most eye or orbital procedures cause only mild to moderate levels of postoperative pain. It can be treated with simple analgesics such as paracetamol, NSAID, and topical anesthetic agents which can be administered beforehand as oral preparations before surgery or intravenous. Meanwhile, in strabismus surgery, evisceration, and vitreoretinal surgery will cause more pain, requiring stronger analgesia. Intraoperative analgesia includes paracetamol, NSAID, intravenous fentanyl and topical local anesthetics, which should be given anytime possible. Such multimodal analgesia should be continued into the postoperative period, with the addition of codeine phosphate or tramadol, and increases to morphine if needed. Opioid use is known to increase the risk of PONV, which makes giving antiemetics essential. ${ }^{4}$

PONV is very common after pediatric eye surgery, and strabismus surgery can reach $60 \%$ if no prophylaxis is given. Administration of ondansetron $0.15 \mathrm{mg} / \mathrm{kgBW}$ has been shown to significantly reduce $\mathrm{PONV}$, and combination therapy like ondansetron and dexamethasone 0.1-0.2 $\mathrm{mg} / \mathrm{kgBW}$ has an even better effect, reportedly reducing the incidence of PONV by as low as $10 \%$ for postoperative strabismus surgery. Most of the pediatric eye procedures are treated as daily cases and the patient can continue the oral intake as early as possible. ${ }^{3,4}$

\section{Conclusion}

In this paper, we have reviewed the general principles of anesthesia management in eye surgery cases, as well as the consideration of anesthesia for some common eye procedures. Pediatric patients tend to require general anesthesia for ophthalmic procedures and surgeries, although most of them are in good health and can be treated as on-day surgery cases. The oculocardiac reflex can be induced during eye surgery and carries a significant risk of bradycardia and can be prevented by giving premedication with anticholinergic agents. Immediate cessation of the manipulation around the eye and extraocular muscle is a very effective way for managing this situation. Thus, intraoperative communication is very important. Postoperative nausea and vomiting (PONV) are common after eye surgery in pediatric patients and can delay discharge if appropriate prophylaxis is not given. Examination procedures under anesthesia (EUA), intraocular surgery, strabismus correction, and vitreoretinal each have their own challenges, which are diferrent from the management of anesthesia, so it is important for anesthetists to understand the considerations of anesthesia in each procedure to provide optimuml care.

\section{References}

1. McGoldrick KE, Gayer SI. Anesthesia for ophthalmologic surgery. In: Barash PG, Cullen BF, Stoelting RK, Cahalan MK, Stock MC, Ortega $\mathrm{R}$, editors. Barash clinical anesthesia. 8th ed. Philadelphia: Wolters Kluwer; 2017. p. 3433-93.

2. Butterworth JF. Mackey DC. Wasnick JD. Morgan \& Mikhail's clinical anesthesiology. $5^{\text {th }}$ Edition. New York: McGraw-Hill Education; 2013. p. 759-68.

3. Davies IDM, Sale SM. Anaesthesia for paediatric eye surgery. Anaesth Intens Care Med. 2017;18(1):37-40.

4. Ahmed D. Updates in pediatric ophthalmic anesthesia. Anaesthesia, Pain Intens Care. 2014;18(1):72-9.

5. Bharati SJ, Chowdhury T, editor. The oculocardiac reflex. Trigeminocardiac Reflex. 2015. p. 89-99.

6. Jean YK, Kam D, Gayer S, Palte HD, Stein ALS. Regional anesthesia for pediatric ophthalmic surgery: a review of the literature. Anesth Analg. 2020;130(5):1351-63.

7. Gayer S. Ophthalmic surgery. In: Allman KG, Wilson IH, O'Donnell AM, editors. Oxford handbook of anaesthesia. 4th ed. United Kingdom: Oxford University Press; 2016. p. 661-81.

8. James I. Anaesthesia for paediatric eye surgery. Contin Educ Anaesthesia, Crit 
Care Pain. 2008;8(1):5-10.

9. Callaway NF, Moshfeghi DM, Jaffe RA. Ophthalmic surgery. In: Jaffe RA, Schmiesing CA, editors. Anesthesiologist's manual of surgical procedures. $5^{\text {th }}$ ed. California: Wolters Kluwer; 2014.

10. Kumar C, Dodds C, Gaye S, editors. Ophthalmic anaesthesia (Oxford Specialist handbooks in anaesthesia). United Kingdom: Oxford University Press; 2012. 11. Arasho B, Sandu N, Spiriev T, Prabhakar $\mathrm{H}$, Schaller B. Management of the trigeminocardiac reflex: facts and own experience. J Neurol India. 2009; 57(4):375-80. 